\title{
Notes
}

\section{Spectrophotometric Determination of Hydrogen Peroxide by a Hydroquinone-Aniline System Catalyzed by Molybdate}

\author{
Eman M. EInemma \\ Chemistry Department, Faculty of Seience. Qatar Liversity, P.O. Box 2713. Doha-Qatar \\ Received April / 2003
}

Key Words : Spectrophotometry. Hydrogen peroxide

Hydrogen peroxide is used widely as an oxidant. a disinfectant and a bleaching agent in various industrial and household products. ${ }^{1.2}$ Micro and trace determination of $\mathrm{H}_{2} \mathrm{O}_{2}$ is considerably important in clinical chemistry, analytical biochemistry and environımental science since $\mathrm{H}_{2} \mathrm{O}_{2}$ is produced in stoichiometric amounts during the oxidation of biological analytes (e.g. glucose) by dissolved oxygen in the presence of corresponding oxidase..$^{1.3}$ Owing to its importance, a large number of analytical methods have been developed for the determination of $\mathrm{H}_{2} \mathrm{O}_{2}$. These methods include titrimetry, ${ }^{5}$ spectrophotometry. ${ }^{6.7}$ fluorescence. ${ }^{9,10}$ enzymatic methods, ${ }^{11}$ chromatographic techniques ${ }^{12,1.3}$ as well as electrochemical methods. ${ }^{1.15}$

Spectrophotometry has been chosen as the preferred method owing to its widespread use in analytical laboratories. At present the most widely used procedures in the determination of $\mathrm{H}_{2} \mathrm{O}_{2}$ are based on the reaction with chromogenic hydrogen donor in the presence of peroxidase or metalloporphyrins as enzyme mimetic of peroxidase. ${ }^{16-18}$ However, peroxidase is expensive and its solutions are very instable whereas the use of metalloporphrins suffers from a very small difference between the absorption maximum of the reagent and the adduct. ${ }^{17}$ An inexpensive procedure based on the reported catalysis of hydrogen peroxide reactions by $\mathrm{Mo}(\mathrm{VI})^{19}$ has been utilized in this study.

\section{Experimental Section}

All chemicals were of analytical reagent grade and were used as received. Aqueous solutions of hydroquinone $(0.25$ $\mathrm{mol} / \mathrm{L})$ and anilinium sulphate $(0.125 \mathrm{~mol} / \mathrm{L})$ and ammonium molybdate $(0.5 \%)$ were made up by weight. Hydrogen peroxide solution $\left(2.0 \times 10^{-i} \mathrm{~mol} / \mathrm{L}\right)$ was prepared by dilution of $30 \% \mathrm{H}_{2} \mathrm{O}_{2}$ (Guaranted Grade). The solution was standardized iodometrically. Buffer solutions were prepared by mixing different amounts of $0.2 \mathrm{~mol} / \mathrm{L} \mathrm{NaOH}$ and 0.2 mol/ $/ \mathrm{KH}_{2} \mathrm{PO}_{4}$ to give solutions with $\mathrm{pH} 6.7,7.0,7.6$. Buffer solutions in the $\mathrm{pH}$ 3-6 range were prepared using varying ratios of solutions of $0.2 \mathrm{~mol} / \mathrm{L} \mathrm{NaOH}$ and $0.2 \mathrm{~mol} / \mathrm{L}$ acetic

"e-mail: eelnemma(àqu.edu.qa acid. Standard buffer solutions of $\mathrm{pH} 4.0$ and 9.2 were supplied by BDH chemicals.

Apparatus. Absorption spectra were measured using UVVIS spectrophotometer (JYE Unican, U K) on a $10 \mathrm{~mm}$ cell. A digital $\mathrm{pH}$ meter equipped with a combined glass-calomel electrode was used for $\mathrm{pH}$ measurements.

Procedure: Determination of $\mathrm{H}_{2} \mathrm{O}_{2}$.

In a $25 \mathrm{~mL}$ colorimetric tube $3.0 \mathrm{~mL}$ of $0.25 \mathrm{~mol} / \mathrm{L}$ hydroquinone, $2.0 \mathrm{~mL}$ of $0.125 \mathrm{~mol} / \mathrm{L}$ anilinium sulphate. $0.1 \mathrm{~mL}$ of $0.5 \%$ ammonium molybdate and varying amounts of standardized $\mathrm{H}_{2} \mathrm{O}_{2}$ solution were mixed and allowed to stand for 10 min. The solution was then diluted to the mark of $25 \mathrm{~mL}$ with distilled water and the absorbance was measured at $550 \mathrm{~nm}$ against a reagent blank in a $10 \mathrm{~mm}$ cell.

\section{Results and Discussion}

The formation of an addition product between the hydroquinone and aniline in the presence of $\mathrm{H}_{2} \mathrm{O}_{2}$ proceed as follows:

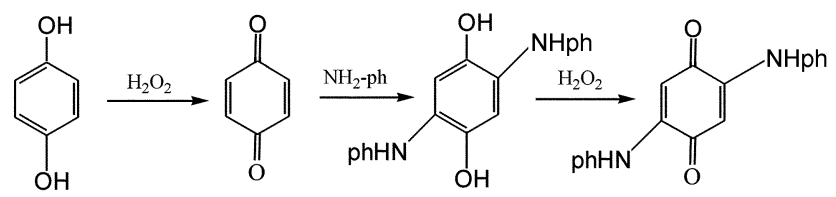

In this system hydroquinone is oxidized to pbenzoquinone by $\mathrm{H}_{2} \mathrm{O}_{2}, 2$ aniline are added, in successive stages, to pbenzoquinone, to yield the disubstituted quinone as the final product. ${ }^{20}$ The UV-VIS spectrum of the product in aquous solution presented in figure 1 . It is obvious that a strong absorption peak with a maximum at $550 \mathrm{~nm}$ is formed.

Effect of $\mathbf{p H}$. The dependence of the system on $\mathrm{pH}$ was studied over the $\mathrm{pH} 3.0-7.0$ range. Figure 2 . shows a flat peak of absorbance obtained in $\mathrm{pH} 3.0-5.0$ range. The absorbance of the system is similar to that obtained in the absence of the buffer. The use of alkaline buffer was excluded because it gave different color.

Effect of time. The absorbance was measured continu- 


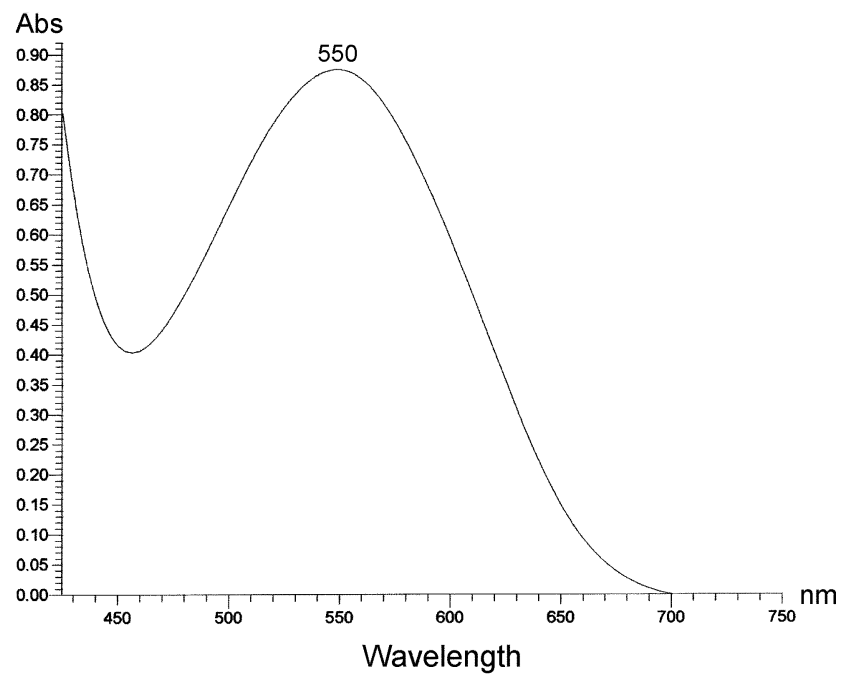

Figure 1. Elcctronic absorption spectrum of the addition product in aqueous solution at $295 \mathrm{~K}$.

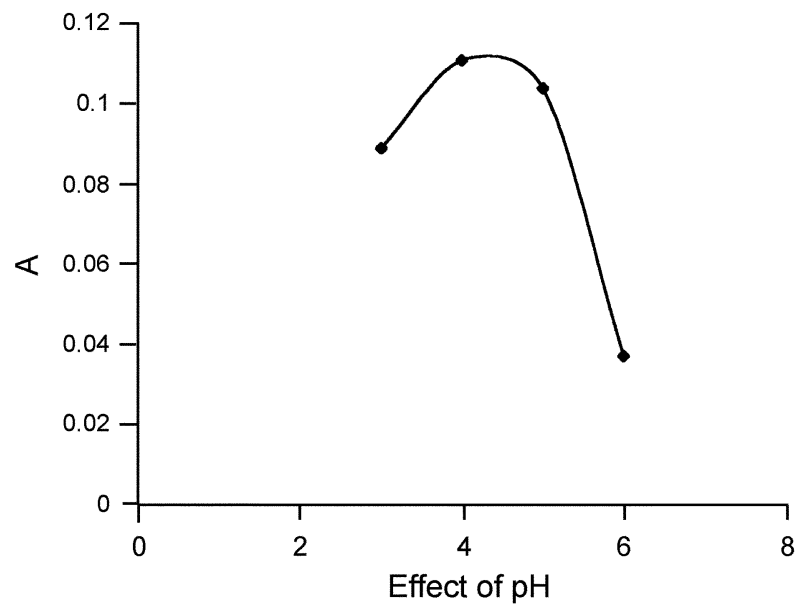

Figure 2. I:liect of pl I on the absorption of the addition product.

ously at room temperature $(\mathrm{rt})$ for $50 \mathrm{~min}$ as shown in Figure 3. After about $12 \mathrm{~min}$.. the absorbance reaches a maximum and remains constant for at least $30 \mathrm{~min}$. Therefore, an incubation period of $15 \mathrm{~min}$. at ( $\mathrm{rt}$ ) was sufficient for the reaction to reach equilibrium.

Order of mixing the reactants. The influence of the addition order of the reagents was followed with four different groups.

Group l:

Hydroquinone + Anilinium sulphate $+\mathrm{MoO}_{4}{ }^{2}+\mathrm{H}_{2} \mathrm{O}_{2}$

Group 11:

Anilinium sulphate $+\mathrm{H}_{2} \mathrm{O}_{2}+\mathrm{Hydroquinone}-\mathrm{MoO}_{4}{ }^{2}$ Group ll]:

Anilinium sulphate $+\mathrm{MoO}_{4}^{2}+\mathrm{H}_{2} \mathrm{O}_{2}-$ Hydroquinone Group IV:

Hydrocuinone $+\mathrm{MoO}_{4}{ }^{2}+\mathrm{H}_{2} \mathrm{O}_{2}+$ Anilinium sulphate

The results of this study demonstrated that the sequences of mixing of groups [ to ll] gave the same result but the sequence of group IV gave no colored product probably

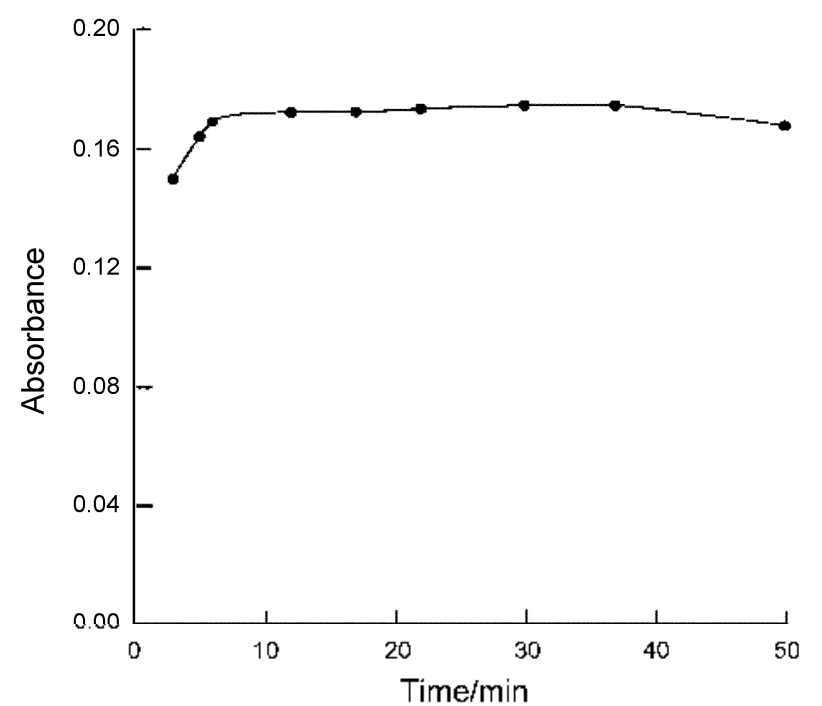

Figure 3. F.f ed of incubation time on the stability of the absorplion of addition product.

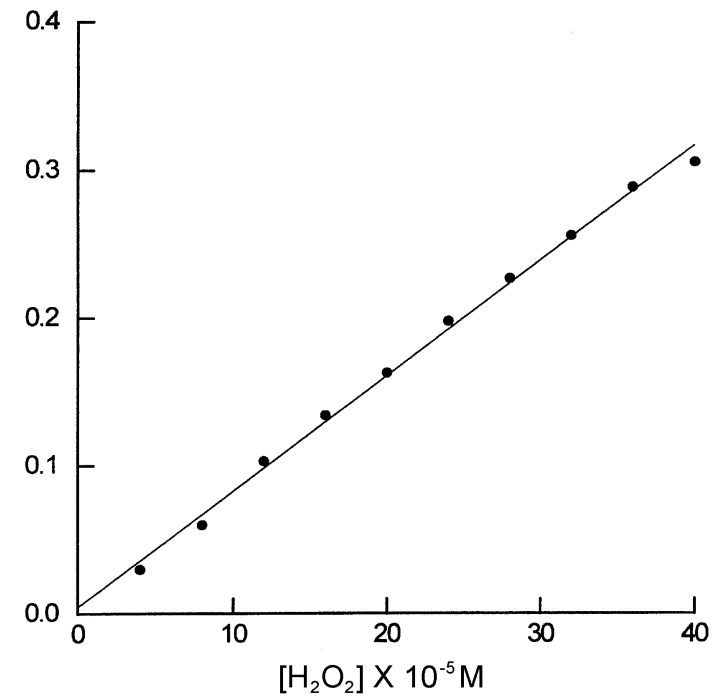

Figure 4. Calibration function for hydrogen peroside.

caused by the oxidation of hydroquinone. Hence it can be infered that the formation of the coloured product only forms when the hydroquinone is oxidized in the presence of aniline. Hence it can be concluded that the correct order of mixing the reactants may follow any of the groups ]-[II.

Effect of amount of reagents. The absorbance is maximal and constant for $4.0 \times 10^{-5}$ mol $/ \mathrm{L} \mathrm{H}_{2} \mathrm{O}_{2}$ when the concentrations of hydroquinone, anilinium sulphate and $\mathrm{MoO}_{4}{ }^{2-}$ are in the range of $2-4 \mathrm{~mL}$ of $0.25 \mathrm{~mol} / \mathrm{L} . .1-3 \mathrm{~mL}$ of $0.125 \mathrm{~mol} / \mathrm{L}$ and $0.1-0.2 \mathrm{~mL}$ of $0.5 \%$ respectively. Accordingly $3.0 \mathrm{~mL}$ of hydroquinone, $2 \mathrm{~mL}$ anilinium sulphate and $0.2 \mathrm{~mL} \mathrm{MoO}_{4}{ }^{2-}$ are recommended for use.

Analytical characteristics. Linearity was shown by the calibration graph shown in Figure 4 for the determination of $\mathrm{H}_{2} \mathrm{O}_{2}$. Regression analysis of the curve is given by

$$
\mathrm{A}-0.00015+0.8 \mathrm{C}
$$


Table 1. Recoveries of hydrogen peroxide

\begin{tabular}{|c|c|c|c|}
\hline $\begin{array}{l}\mathrm{H}_{2} \mathrm{O}_{2} \text { content of artificaial } \\
\text { sample, }\left(\times 10^{-5} \mathrm{~mol} / \mathrm{L}\right)\end{array}$ & $\begin{array}{c}\text { Added } \\
\left(\times 10^{-4} \mathrm{~mol} / \mathrm{L}\right)\end{array}$ & $\begin{array}{c}\text { Found } \\
\left(\times 10^{-4} \mathrm{~mol} / \mathrm{L}\right)\end{array}$ & $\begin{array}{c}\text { Recovery } \\
(\%)\end{array}$ \\
\hline 8 & 0 & $\begin{array}{l}8.0,8.3,8.6 \\
7.9,7.8,8.0\end{array}$ & \\
\hline 8 & 4 & $\begin{array}{l}11.5,11.8 \\
12.2,11.5 \\
12.0,12.3\end{array}$ & 99.03 \\
\hline 8 & 8 & $\begin{array}{l}16.0,16.3 \\
16.6,15.9 \\
15.8,16.0\end{array}$ & 100.63 \\
\hline
\end{tabular}

Table 2. Effect of interferences of inorganic salts $\left[\mathrm{H}_{2} \mathrm{O}_{2}\right]=2.0 \times$ $10^{-4} \mathrm{~mol} / \mathrm{L}$

\begin{tabular}{lcc}
\hline Substance & Amount $(\mu \mathrm{g} / \mathrm{mL})$ & Enor $(\%)$ \\
\hline $\mathrm{Br}^{-}$ & 160 & -0.5 \\
$\mathrm{SO}_{4}{ }^{2-}$ & 1150 & 0 \\
$\mathrm{NO}_{3}^{-}$ & 370 & 0 \\
$\mathrm{HPO}_{4}{ }^{-}$ & 1.6 & -7.6 \\
$\mathrm{Fe}^{3+}$ & 0.84 & 0 \\
$\mathrm{Mg}^{2+}$ & 72.9 & 0 \\
$\mathrm{Ag}^{+}$ & 0.26 & 0 \\
$\mathrm{~K}^{+}$ & 234 & 0 \\
\hline
\end{tabular}

when the concentration of $\mathrm{H}_{2} \mathrm{O}_{2}$ was $3.8 \times 10^{-4} \mathrm{~mol} / \mathrm{L}$, and the apparent absorptivity was $8.0 \times 10^{2} \mathrm{~L} / \mathrm{mol}$.cm. The coefficient of variation for the deternination of $6.0 \times 10^{-5}$ $\mathrm{mol} / \mathrm{L} \mathrm{H}_{2} \mathrm{O}_{2}$ was $99.99 \%(\mathrm{n}=6)$. Sandell sensitivity was $0.043 \mu \mathrm{g} / \mathrm{mL}$

A definite store of $\mathrm{H}_{2} \mathrm{O}_{2}$ and the reagents were added in the determination of $\mathrm{H}_{2} \mathrm{O}_{2}$ then the recovery values were deternined by their absorbance fron the calibration graph so the recoveries of artificial sample were investigated as listed in Table 1 .

The interference of foreign substances in the determination of $\mathrm{H}_{2} \mathrm{O}_{2}\left(2.0 \times 10^{-4} \mathrm{~mol} / \mathrm{L}\right)$ was examined. The salt concentrations were five times higher than the limiting concentration specified in drinking water. The results of interference are summarized in Table 2.

In conclusion, the new method based on the addition product formation has been demonstrated to be reliable and with acceptable sensitivity for the determination of hydrogen peroxide in verities of product.

\section{References}

1. Forbe. C. L. Pulp Pap. 1992. 66(1) 90

2. Li. Y. Food Chent. Toxicol. 1996. 34. 887.

3. Bower, L. D. Anal Chem. 1986, $513 \mathrm{~A}$

4. Kabasakaliam. P. Kalliney, S.; Westoett, A. Chin. Chent 1974, 20. 606.

5. Greenspant. F. P.: McKellar. D. G. And. Chem. 1949. 20. 1061.

6. Graf. E.: Penniston. J. T. Clm. Chem. 1980. 26.658.

7. Sellers. R. M. Anahst 1980.105 .950$.

8. Wolf, W. C. Anal Chem. 1962,34.1328

9. Andreae. W. A. Natme $1955,175,859$

10. Guilbault, G. G.: Brignac Jr.. P. J.: Juneau, M. Anat. Chem 1968. 40. 1256.

11. Gallati. H. I. Chi. Chem. Chin. Biochem. 1979. 17.1.

12. Lee. M.: Noone. C. B.: O'Sulivan. D.: Heikes. B. G. J. Atonts. Oceanic Techmol 1995, 12. 1060

13. Kobayashi. K.; Kawai. S. J. Chomatogr 1982. 245, 339.

14. Iswase, K. S.; Tanaka. N. Anal Chim Acta 1979. 110. 157.

15. Lin. M. S.: Tan. B. I. Electroandysis 1997. 9. 340.

16. Guo. Z. X.: Shet1. H.X.: Li. L. Mhikodhm Acta 1999. 131. 171 .

17. Schmid. M.: Krebs, B. Karst Anahst 1998. 123, 2323

18. Huang. X.-M.: Zhu. M.; Shen. H.-X. Mikrochim Acta 1998, 128. 87.

19. Aubry. T. M.: Bouttemy. S. J. Am. Chem Soc. 1997. 119. 5286.

20. Geissan. T. A. Principle of Onganic Chemistry. W. H. Freeman and Company: San Franciso. U.S.A. 1997: p 769. 